\title{
Diagnostic accuracy of videofluoroscopy for symptomatic cervical spine injury following whiplash trauma
}

Michael D Freeman ( $\square$ m.freeman@maastrichtuniversity.nl)

Maastricht University CAPHRI School for Public Health and Primary Care https://orcid.org/0000-00030228-3158

\section{Evan A Katz}

Private practice

\section{Scott L. Rosa}

Private practice

\section{Bryan D Gatterman}

Life Chiropractic College West

\section{Ellen M F Strömmer}

Universiteit Maastricht Care and Public Health Research Institute

\section{Wendy M Leith}

Forensic Research + Analysis

\section{Research article}

Keywords: whiplash, instability, videofluoroscopy, digital motion x-ray, positive predictive value

Posted Date: November 22nd, 2019

DOI: https://doi.org/10.21203/rs.2.17732/v1

License: (c) (i) This work is licensed under a Creative Commons Attribution 4.0 International License. Read Full License 


\section{Abstract}

\section{Background}

Intervertebral instability is a relatively common finding among patients with chronic neck pain after whiplash trauma. Videofluoroscopy (VF) of the cervical spine is a potentially sensitive diagnostic tool for evaluating instability, as it offers the ability to examine relative intervertebral movement over time, and across the entire continuum of voluntary movement of the patient. At the present time there are no studies of the diagnostic accuracy of VF for discriminating between injured and uninjured populations.

\section{Methods}

Symptomatic (injured) study subjects were recruited from consecutive patients with chronic (>6 weeks) post-whiplash pain presenting to medical and chiropractic offices equipped with VF facilities.

Asymptomatic (uninjured) volunteers were recruited from family and friends of patients. Ethical review and oversight was provided by the Spinal Injury Foundation, Broomfield, CO. Three statistical models were utilized to assess the sensitivity, specificity, positive and negative predictive values (PPV and NPV) of positive VF findings to correctly discriminate between injured and injured subjects.

\section{Results}

All 3 models demonstrated high levels of sensitivity and specificity (i.e. ROC values of 0.71 to 0.95 ), however, the model with the greatest practical clinical utility was based on the number of abnormal VF findings. For 2+ abnormal VF findings the ROC was 0.88 (93\% sensitivity, $79 \%$ specificity), and the PPV and NPV were both $88 \%$.

\section{Conclusions}

Videofluoroscopic examination of the cervical spine provides a high degree of diagnostic accuracy for identification of vertebral instability in patients with chronic pain stemming from whiplash trauma.

\section{Background}

Neck pain is a highly prevalent condition, occurring in $10-21 \%$ of the adult population annually.[1] A frequent cause of both acute and chronic neck pain is injury from a motor vehicle crash (MVC).[2] Although a variety of spinal injuries are associated with MVCs, the most common injury type is musculoligamentous sprain or strain.[3] Such injuries often result from the type of whiplash trauma that is closely associated with rear impact crashes. The term "whiplash" refers to a traumatic whipping motion of the head and neck, primarily occurring in rear impact crashes, that produces higher peak acceleration at the head than in the neck or thoracolumbar spine.[4] While some authors have also used "whiplash" as 
a generic catch-all description for a variety of injuries resulting from whiplash trauma, when used to describe an injury the term generally refers to cervical spine sprain/strain injury.[5]

A feature of whiplash trauma is injury to and resulting laxity of the ligaments of the cervical spine.[6, 7] Intervertebral instability associated with ligamentous injury can be both difficult to detect and refractory to treatment.[8] Because the diagnosis of vertebral "instability" refers to an abnormality of function, the condition is typically not identifiable from static postural radiographs and may be occult to other conventional imaging (i.e., MRI and CT) and thus is prone to underdiagnosis.[9]

Fluoroscopic examination of the spine (a.k.a. videofluoroscopy [VF], or digital motion x-ray [DMX]) allows for a continuous and minute examination of movement within the cervical spine, including abnormalities of intervertebral motion associated with ligamentous instability.[10] VF records 30 images per second of continuous $\mathrm{x}$-ray of active range of motion across multiple planes, allowing for a dynamic fourdimensional visualization of the integrity of the ligaments of the upper, mid, and lower cervical spine.[10, 11] Typically, cervical spine VF motion studies include a lateral view of flexion and extension (to examine anterior to posterior intervertebral instability), and anterior to posterior views of bilateral flexion with the mouth closed (to evaluate for excessive facet gapping in the mid and lower cervical spine), and the mouth open (to evaluate for lateral instability of $\mathrm{C} 1$ on $\mathrm{C} 2$ ). The studies provide evidence of the functional integrity of the ligamentum flavum, anterior and posterior longitudinal, interspinous, supraspinous and facet capsular ligaments in the mid and lower cervical spine (C2-7), and the alar and transverse ligaments in the upper cervical spine (CO-2). $[7,8,12]$

Although prior authors have examined the interrater reliability of VF for detecting cervical spine instability, [13] at the present time there are no published studies describing the diagnostic accuracy (e.g., positive and negative predictive values) of VF for detecting symptomatic whiplash trauma-associated instability. The goal of the present study is therefore to provide a quantitative assessment of the ability of VF to discriminate between patients with symptomatic post-traumatic neck pain versus asymptomatic controls.

\section{Methods}

The study population was drawn from consecutive patients and patient relatives or acquaintances presenting to 11 chiropractic or medical offices with an available on-site VF facility. The inclusion criterion for all subjects was age 16-65 years and an absent history of cervical fracture, congenital anomaly, inflammatory arthritis, diagnosed connective tissue disorders, metastatic disease of the spine, or any other bony or neurological abnormality that was deemed to have potentially affected the results of a VF examination. Symptomatic (injured) subjects were recruited from patients actively seeking treatment for subacute or chronic neck pain persisting for more than 6 weeks after a traffic crash-related acute neck injury. Asymptomatic (uninjured) patients were recruited from relatives or acquaintances of patients presenting to the offices, and who did not, in the prior year, have a history of either chronic neck pain or episodic neck pain persisting for $>1$ week. 
There were 5 VF motion view examination s of the cervical spine included in the study; 1 ) an anterior to posterior (A-P) view of the entire cervical spine, with right and left lateral flexion to the comfort of the patient; 2) A-P view of the upper cervical spine with the mouth open, with right and left lateral flexion to the comfort of the patient; and 3) lateral view with flexion and extension to the comfort of the patient, and 4-5) right and left oblique views with flexion and extension to the comfort of the patient. The limit of translation (slippage) used as the expected threshold for "normal" spines was $2 \mathrm{~mm}$ based on the socalled "rule of 2's",[14] as fewer than $10 \%$ of the spines of the uninjured and asymptomatic study group would be expected to exceed this degree of slip.[15,16] The upper threshold of normal intervertebral flexion used for the study was 10 degrees.[17] Other parameters used for assessing the VF studies are described in further detail in Table 1.

Two raters trained in radiology and experienced in interpreting VF examinations evaluated the 5 studies of each patient for intervertebral movement from C1-C7. The raters were blinded as to prior interpretation of the studies. Details of measurement/ assessment category choices for the VF readers are listed in Table 2. Where the raters disagreed, the more conservative (normal) of the 2 ratings was used to reduce the risk of Type I (false positive) error. The ratings were then dichotomized into either the "expected normal" finding or not (i.e. abnormal) as detailed in Table 2.

The data were first evaluated for differences between the symptomatic and asymptomatic patients with respect to age, sex, and abnormal VF findings (see Table 3). The differences in average age and total number of abnormal VF findings were evaluated with t-tests, while the categorical variables were evaluated with chi-square tests. The data were then randomly split into a $75 \%$ training data set, and a $25 \%$ testing data set. The training data set was used to build models to identify injured patients based on a) combinations of VF measures, age, and sex as established by stepwise logistic regression (entry pvalue $=0.20$; exit $p$-value $=0.05$ ); $b$ ) the total number of abnormal readings as a continuous variable in an adjusted logistic regression model including age and sex; and c) a cut-point analysis to establish a threshold for dichotomous classification of the total number of abnormal readings. The training model predictive value was quantified with the area under the receiver operating characteristic curve (ROC), while lack of fit was evaluated with the Hosmer-Lemeshow Goodness of Fit Test. The testing data set was used to verify the predictive ability of the models by examining the sensitivity (probability that the test would correctly identify injured patients), and specificity (probability that the test would correctly identify uninjured volunteers). Positive predictive value (PPV) and negative predictive value (NPV) were also calculated for the models. PPV quantifies the probability that an individual with a positive test is an injured patient, and NPV is the probability an individual with a negative test is an uninjured volunteer.

All analyses were performed using SAS Software, Version 9.4.

\section{Results}

A total of 196 subjects were recruited for inclusion in the study, divided into 77 (39.3\%) asymptomatic/ uninjured volunteers and 119 (60.7\%) symptomatic/ injured patients (Table 3 ). The symptomatic patients 
were significantly more likely to be female $(75.6 \%$ vs $46.8 \%$; p-value $<0.0001)$, and significantly older (40.5 vs $33.9 ; p=0.0006)$.

The uninjured volunteers had substantially fewer abnormal VF readings across all 37 combinations of measures and spinal levels (average 7.0 vs 1.2 per patient; $p<0.0001$ ); none of the uninjured volunteers had abnormal findings for 17 of the measured parameters, and only 3 of the parameters were positive for abnormality in $>10 \%$ of the asymptomatic group (C1-2 overhang, and C3-4 and C4-5 translation). In comparison, among the injured patients there was at least 1 subject with abnormality in all of the $37 \mathrm{VF}$ parameters, and in 23 the number of abnormal subjects exceeded $10 \%$ of the total. There were 24 of the VF parameters in which there was a statistically significant difference between the 2 study groups; in all cases the frequency among the injured patients was greater than among the uninjured volunteers. See Table 3 for more details.

Three predictive statistical models were examined in order to determine the model with the highest degree of diagnostic accuracy for differentiating between injured patients and uninjured volunteers. These models and their results were as follows:

\section{Model 1}

Stepwise logistic regression using all VF parameters, as well as age and sex. Entry $p$-value $=0.20$. Exit $p$ value $=0.05$.

Model 1 results: The only single VF parameter found to be a significant predictor for symptomatic patient status was $\mathrm{C} 4-\mathrm{C} 5$ facet gapping. The ROC was 0.71 , and the likelihood that a patient with an abnormal C4-C5 facet gapping finding would be symptomatic was 44.9 times greater than a patient with a normal C4-C5 facet gapping finding (95\% $\mathrm{Cl}[5.9,339.3])$. The sensitivity and NPV were 0.53 and 0.58 respectively, while the specificity and PPV were both 1 (See Table 4). Lack of fit could not be assessed.

\section{Model 2}

Logistic regression using the total number of abnormal findings as a continuous measure, adjusted for age and sex.

Model 2 Result: The total number of abnormal findings resulted in a model with a ROC of 0.94 , indicating near-perfect prediction in the training data. The odds that the subject was injured increased by 2.6 for each additional abnormal finding (95\% CI $[1.79,3.69])$. Neither age nor sex were significant after accounting for the number of abnormal findings. The sensitivity and PPV were both 0.93 , while the specificity and NPV were 0.89 (see Table 4). The model did not suffer from lack of fit.

\section{Model 3}

Cut-point analysis examining the predictive ability of a dichotomization of the number of abnormal findings across a range of values ( 2 or more abnormal findings [2+], 3 or more abnormal findings [3+], 
etc.), adjusted for age and sex.

Model 3 results: The ROC increased from 0.88 for the model dichotomized at 2 or more abnormal findings, to 0.92 for the $3+$ and $4+$ models, and then decreased for the model dichotomized at 5 or more abnormal findings. The specificity attained a maximum value for the $2+$ and $3+$ models $(0.93)$, while the specificity was maximized for the 4+ model (see Table 4). PPV hit a maximum (1) in the 4+ model, while NPV was maximized (0.89) in the $3+$ model. None of the cut-point models with the exception of the 5+ dichotomization suffered from lack of fit. A comparison of the diagnostics for each of the models is illustrated in Figure 1.

\section{Discussion}

These results provide convincing evidence for several conclusions: 1 ) intervertebral instability is a common finding in the symptomatic population of patients with chronic neck pain after whiplash trauma; 2) intervertebral instability is an uncommon finding in the uninjured population; 3 ) the finding of 2 or more abnormal parameters of intervertebral motion on videofluoroscopic examination of the cervical spine is a highly accurate diagnostic test for identifying patients with chronic neck pain after whiplash trauma.

The findings in the present study demonstrate a common pathological entity (ligamentous laxity) in the population of patients with chronic pain after whiplash, and one that can be identified with a relatively common diagnostic examination. These findings make sense given the fact that injury to the spinal ligaments, and particularly those of the facet capsule, is readily explained from the known pathomechanics of whiplash trauma, in which focal intersegmental hyperextension and hyperflexion have the potential to produce excessive strain (stretch) of the intervertebral ligaments.[18]

These findings have importance given a number of prior publications demonstrating equivocal or negative MRI results in patients with acute and chronic whiplash, a body of literature that has been transformed into a myth that whiplash is a "soft-tissue" injury that cannot be detected with medical imaging.[19] The repetition of this myth has in turn, resulted in a number of non-organic, and pejorative explanations for chronic pain complaints after whiplash trauma, including symptom exaggeration, malingering, and secondary gain.[20,21] Given the high prevalence of ligament injury in the chronic whiplash population, and the lack of such findings in the uninjured population, the attribution of complaints to a nonorganic source in any chronic whiplash patient without first ruling out pathology via $\mathrm{VF}$ imaging of the cervical spine is unfounded.

A finding in the present study that required further investigation was the $3 \mathrm{VF}$ parameters that occurred at a higher than expected rate $(>10 \%)$ in the uninjured versus injured group: C1-2 lateral overhang difference (32.5\% vs. $63.6 \%)$, C3-4 translation ( $11 \%$ vs. $11.7 \%$ ), and C4-5 translation ( $24.7 \%$ vs. $48.7 \%)$, respectively. The most direct explanation for these findings is that, for these measures, the cut-point of $>2 \mathrm{~mm}$ translation (difference or absolute measure) for "abnormal" was too low. A re-examination of the data using $4 \mathrm{~mm}$ and below as the cut-point for "normal" demonstrated that this was indeed the case. For C1-2 
lateral overhang the frequency of abnormal findings among the uninjured volunteers decreased to $5.2 \%$, whereas $34.2 \%$ of the injured group were still categorized as abnormal. At C3-4 the increase in the normal cut point to $4 \mathrm{~mm}$ or less eliminated all but 1 of the abnormal translation findings (and the only remaining abnormality was found in the uninjured group). At C4-5 the increased cut point eliminated all of the abnormal findings in the uninjured group, and decreased the frequency of abnormal findings in the injured group to $10.5 \%$. These results indicate that universal reliance on the "rule of 2 's" in all circumstances may increase the risk of false positives in VF for individual measures. This caveat does not apply to the statistical models described in the present study; the high PPV probabilities associated with $2+, 3+$, and $4+$ positive findings were all based on the $2+\mathrm{mm}$ threshold for abnormality (for the measured parameters).

A caveat to keep in mind when interpreting these results and applying them to the general clinical population is that interrater agreement (Cohen's kappa) between the 2 experienced VF readers ranged from only moderate $(>0.4-0.6)$ for the injured patients to good $(>0.6-0.8)$ for the uninjured volunteers. The impact of this interrater variability on the study results was minimized by use of the most conservative (i.e. normal) of the 2 ratings when the raters disagreed. As far more of the injured patients than the uninjured volunteers had abnormal findings this strategy lessened the differences between the groups, thus decreasing the risk of Type I error. Regardless, as with many medical imaging modalities, potential variability in the interpretation of VF studies should be recognized in assessing the results reported by a single reader.

\section{Conclusions}

Videofluoroscopic (or DMX) examination of the cervical spine is a highly accurate test for identifying patients with symptomatic ligamentous instability after whiplash trauma. The imaging modality should be utilized more widely in the clinical investigation of chronic post-whiplash pain.

\section{Abbreviations}

VF - videofluoroscopy; DMX - digital motion x-ray; PPV - positive predictive value; NPV - negative predictive value; ROC - receiver operating characteristic; $M R I$ - magnetic resonance imaging; $C T$ computed tomography.

\section{Declarations}

\section{Competing Interests}

The authors declare that they have no competing interests.

\section{Ethics Approval and Consent to Participate}


Ethical oversight and approval was provided by a non-profit institutional review board (Spinal Injury Foundation-IRB00002637) in Broomfield, CO, registered with the US Department of Health and Human

Services. Verbal informed consent was deemed adequate due to minimal risk, and was obtained from all study subjects in accordance with the IRB approved protocol.

Consent to Publish

Not applicable.

\section{Authors' Contributions}

MF contributed to the study conception, design, analysis, and drafting of the manuscript. EK contributed to the study design, acquisition and interpretation of data. SR contributed to the study design and interpretation of data. BG contributed to the study design and interpretation of data. ES contributed to the study design and analysis of data. WL contributed to the study design, analysis, and drafting of the manuscript. All authors have approved the submitted version of the manuscript and have agreed both to be personally accountable for their own contributions and to ensure that questions related to the accuracy or integrity of any part of the work, even ones in which the author was not personally involved, are appropriately investigated, resolved, and the resolution documented in the literature.

\section{Acknowledgement}

The authors thank the following individuals who contributed time, expertise, and resources to the study: Drs. Brian Irvine, Mike Szatalowicz, Steve Whitelaw, Nathan Unruh, Ron Brodkin, Ed Harkins, James Fuller, and Brad Dreifuss.

\section{Funding}

No outside funding was used for the study.

Availability of Data and Materials

All data generated or analyzed during this study are included in this published article [and its supplementary information files].

\section{References}

1. Hoy DG, Protani M, De R, Buchbinder R (2010) The epidemiology of neck pain. Best Pract Res Clin Rheumatol 24:783-792. https://doi.org/10.1016/J.BERH.2011.01.019

2. Nolet PS, Emary PC, Kristman VL, et al (2019) Exposure to a Motor Vehicle Collision and the Risk of Future Neck Pain: A Systematic Review and Meta-Analysis. PM\&R pmrj.12173. https://doi.org/10.1002/pmrj.12173 
3. Insurance Research Council (2008) Auto injury insurance claims: countrywide patterns in treatment, cost, and compensation. Malvern, PA

4. McConnell WE, Howard RP, Guzman HM, et al (1993) Analysis of Human Test Subject Kinematic Responses to Low Velocity Rear End Impacts. SAE Technical Paper 930889

5. Westergren $\mathrm{H}$, Larsson J, Freeman M, et al (2018) Sex-based differences in pain distribution in a cohort of patients with persistent post-traumatic neck pain. Disabil Rehabil 40:. https://doi.org/10.1080/09638288.2017.1280543

6. Ivancic $P$, Ito $S$, Tominaga $Y$, et al (2008) Whiplash causes increased laxity of cervical capsular ligament. Clin Biomech 23:159-65

7. Tominaga $Y, N d u A B$, Coe MP, et al (2006) Neck ligament strength is decreased following whiplash trauma. BMC Musculoskelet Disord 7:103. https://doi.org/10.1186/1471-2474-7-103

8. Steilen D, Hauser R, Woldin B, Sawyer S (2014) Chronic neck pain: Making the connection between capsular ligament laxity and cervical instability. Open Orthop J 8:326-45

9. Uhrenholt L, Gregersen M, Charles AV, et al (2010) [Examinations of the deceased can contribute to the understanding of whiplash injuries after traffic accidents]. Ugeskr Laeger 172:3129; author reply 3129

10. Cholewicki J, McGill S, Wells R, Vernon H (1991) Method for measuring vertebral kinematics from videofluoroscopy. Clin Biomech 8:73-8

11. Derrick LJ, Chesworth BM (1992) Post-motor vehicle accident alar ligament laxity. J Orthop Sports Phys Ther 16:6-11. https://doi.org/10.2519/jospt.1992.16.1.6

12. Krakenes J, Kaale B, Moen G, et al (2002) MRI assessment of the alar ligaments in the late stage of whiplash injury - a study of structural abnormalities and observer agreement. Neuroradiology 44:617-624. https://doi.org/10.1007/s00234-002-0799-6

13. Croft AC, Krage J, Pate D, Young D (1994) Videofluoroscopy in cervical spine trauma: An interinterpreter reliability study. J Manipulative Physiol Ther 17:20-4

14. Daffner RH (2011) Imaging of Vertebral Trauma, 3rd ed. Cambridge University Press

15. Park MS, Moon S-H, Lee H-M, et al (2013) The natural history of degenerative spondylolisthesis of the cervical spine with 2- to 7-year follow-up. Spine (Phila Pa 1976) 38:E205-10

16. Kopacz KJ, Connolly PJ (1999) The prevalence of cervical spondylolisthesis. Orthopedics 22:677-9

17. Rondinelli RD, Genovese E, Brigham CR, American Medical Association. (2008) Guides to the evaluation of permanent impairment., 6th ed. American Medical Association, Chicago, IL

18. Siegmund GP, Winkelstein BA, Ivancic PC, et al (2009) The Anatomy and Biomechanics of Acute and Chronic Whiplash Injury. Traffic Inj Prev 10:101-112. https://doi.org/10.1080/15389580802593269

19. Pettersson K, Hildingsson C, Toolanen G, et al (1994) MRI and neurology in acute whiplash trauma: No correlation in prospective examination of 39 cases. Acta Orthop Scand 65:525-528. https://doi.org/10.3109/17453679409000906 
20. Ferrari R, Kwan O, Russell AS, et al (1999) The best approach to the problem of whiplash? One ticket to Lithuania, please. Clin Exp Rheumatol 17:321-6

21. Schmand B, Lindeboom J, Schagen S, et al (1998) Cognitive complaints in patients after whiplash injury: the impact of malingering. J Neurol Neurosurg Psychiatry 64:339-43. https://doi.org/10.1136/jnnp.64.3.339

Tables

Table 1. Measured parameters of VF views/motions.

\begin{tabular}{|c|c|c|c|c|}
\hline $\begin{array}{l}\text { Anatomical/ } \\
\text { biomechanical } \\
\text { parameter } \\
\text { (view) }\end{array}$ & $\begin{array}{l}\text { Vertebral } \\
\text { level }\end{array}$ & $\begin{array}{l}\text { VF motion } \\
\text { examination/ } \\
\text { view details }\end{array}$ & Measurement details & $\begin{array}{l}\text { Expected normal } \\
\text { values }\end{array}$ \\
\hline $\begin{array}{l}\text { Lateral } \\
\text { overhang } \\
(\mathrm{AP})\end{array}$ & C1-2 & $\begin{array}{l}\text { A-P open } \\
\text { mouth R\&L } \\
\text { lateral } \\
\text { flexion }\end{array}$ & $\begin{array}{l}\text { Maximum difference in lateral translation (in } \\
\text { mm) of the lateral margin of the lateral mass } \\
\text { of } C 1 \text { relative to the lateral margin of the } \\
\text { superior articular facet of } C 2 \text {, between sides }\end{array}$ & $\begin{array}{l}2 \mathrm{~mm} \text { or less } \\
\text { overhang } \\
\text { difference } \\
\text { between sides }\end{array}$ \\
\hline $\begin{array}{l}\text { Peri-odontoid } \\
\text { space } \\
\text { symmetry } \\
(\mathrm{AP})\end{array}$ & C1-2 & $\begin{array}{l}\text { A-P open } \\
\text { mouth } R \& L \\
\text { lateral } \\
\text { flexion }\end{array}$ & $\begin{array}{l}\text { Bilateral symmetry of gap between dens of C2 } \\
\text { and medial margin of lateral mass of C1, } \\
\text { observed at extreme R\&L flexion }\end{array}$ & $\begin{array}{l}\text { Symmetrical gap } \\
\text { maintained }\end{array}$ \\
\hline $\begin{array}{l}\text { Translation } \\
\text { (lat) }\end{array}$ & $\mathrm{C} 2-7$ & $\begin{array}{l}\text { Lateral } \\
\text { flexion- } \\
\text { extension }\end{array}$ & $\begin{array}{l}\text { Maximum anterior (in flexion) or posterior (in } \\
\text { extension) translation of vertebral body } \\
\text { relative to adjacent inferior vertebra, } \\
\text { measured at posterior vertebral body line }\end{array}$ & $\begin{array}{l}2 \mathrm{~mm} \text { or less } \\
\text { anterior or } \\
\text { posterior } \\
\text { translation }\end{array}$ \\
\hline $\begin{array}{l}\text { Intervertebral } \\
\text { angulation } \\
\text { (lat) }\end{array}$ & $\mathrm{C} 2-7$ & $\begin{array}{l}\text { Lateral } \\
\text { flexion- } \\
\text { extension }\end{array}$ & $\begin{array}{l}\text { Angle between adjacent posterior vertebral } \\
\text { body lines in maximum flexion }\end{array}$ & $\begin{array}{l}10 \text { degrees or } \\
\text { less }\end{array}$ \\
\hline $\begin{array}{l}\text { SP } \\
\text { engagement } \\
\text { (lat) }\end{array}$ & $\mathrm{C} 2-7$ & $\begin{array}{l}\text { Lateral } \\
\text { flexion- } \\
\text { extension }\end{array}$ & $\begin{array}{l}\text { Degree of synchronous movement between } \\
\text { adjacent spinous processes during flexion } \\
\text { from neutral }\end{array}$ & $\begin{array}{l}\text { Inter-spinous } \\
\text { process distance } \\
\text { increases } \\
\text { commensurately } \\
\text { with flexion }\end{array}$ \\
\hline $\begin{array}{l}\text { SP coupled } \\
\text { movement } \\
\text { (AP) }\end{array}$ & C2-7 & $\begin{array}{l}\text { AP c-spine } \\
\text { R\&L lateral } \\
\text { flexion }\end{array}$ & $\begin{array}{l}\text { Degree of coupled spinous process rotation } \\
\text { with ipsilateral flexion }\end{array}$ & $\begin{array}{l}\text { Spinous process } \\
\text { rotates during } \\
\text { lateral flexion }\end{array}$ \\
\hline $\begin{array}{l}\text { Facet gapping } \\
\text { (AP) }\end{array}$ & $\mathrm{C} 2-7$ & $\begin{array}{l}\text { AP c-spine } \\
\text { R\&L lateral } \\
\text { flexion }\end{array}$ & $\begin{array}{l}\text { Degree of separation at facet during maximal } \\
\text { lateral flexion }\end{array}$ & $\begin{array}{l}\text { No appreciable } \\
\text { gapping at } \\
\text { maximum lateral } \\
\text { flexion }\end{array}$ \\
\hline $\begin{array}{l}\text { Facet gapping } \\
\text { (obl) }\end{array}$ & $\mathrm{C} 2-7$ & $\begin{array}{l}\text { R\&L oblique } \\
\text { C-spine } \\
\text { flexion- } \\
\text { extension }\end{array}$ & $\begin{array}{l}\text { Degree of separation at facet during maximal } \\
\text { forward flexion }\end{array}$ & $\begin{array}{l}\text { No appreciable } \\
\text { gapping at } \\
\text { maximum } \\
\text { forward flexion }\end{array}$ \\
\hline $\begin{array}{l}\text { Facet } \\
\text { symmetry } \\
\text { (obl) }\end{array}$ & $\mathrm{C} 2-7$ & $\begin{array}{l}\text { R\&L oblique } \\
\text { c-spine } \\
\text { flexion- } \\
\text { extension }\end{array}$ & $\begin{array}{l}\text { Degree of symmetrical movement at facets } \\
\text { during flexion and extension, comparing right } \\
\text { and left }\end{array}$ & $\begin{array}{l}\text { Movement and } \\
\text { degree of } \\
\text { gapping is } \\
\text { symmetrical } \\
\text { between sides }\end{array}$ \\
\hline
\end{tabular}

Abbreviations: $\mathrm{AP}=$ anterior to posterior view, lat $=$ lateral view, obl $=$ oblique view, $\mathrm{mm}=$ millimeters, $\mathrm{R} \& \mathrm{~L}=$ right and left, $\mathrm{SP}=$ spinous process, $\mathrm{c}$-spine = cervical spine 
Table 2. Definitions used for each VF parameter measurement. 


\begin{tabular}{|c|c|c|}
\hline & Measurements & Dichotomous recode \\
\hline C1-2 lateral overhang (AP view) & $\begin{array}{l}\cdot 0-2 \mathrm{~mm} \\
\text { - }>2-4 \mathrm{~mm} \\
\text { - }>4-6 \mathrm{~mm} \\
\text { - }>6 \mathrm{~mm}\end{array}$ & $\begin{array}{l}\text { - } 0-2 \mathrm{~mm} \\
->2 \mathrm{~mm}\end{array}$ \\
\hline $\begin{array}{l}\text { C1-2 peri-odontoid } \\
\text { symmetry (AP view) }\end{array}$ & $\begin{array}{l}\text { - Symmetrical } \\
\text { - Mildly-Asymmetrical } \\
\text { - Asymmetrical } \\
\end{array}$ & $\begin{array}{l}\text { - Symmetrical } \\
\text { - Asymmetrical }\end{array}$ \\
\hline C2-7 translation (lat view) & $\begin{array}{l}\cdot 0-2 \mathrm{~mm} \\
\cdot>2-3 \mathrm{~mm} \\
\cdot>3-4 \mathrm{~mm} \\
\text { - }>4 \mathrm{~mm}\end{array}$ & - $0-2 \mathrm{~mm}$ \\
\hline $\begin{array}{l}\text { C2-7 inter-vertebral } \\
\text { angulation (lat view) }\end{array}$ & $\begin{array}{l}-<10 \text { degrees } \\
\text { - } 10+\text { degrees }\end{array}$ & $\begin{array}{l}\text { - } \quad<10 \text { degrees } \\
\text { - } 10+\text { degrees } \\
\end{array}$ \\
\hline $\begin{array}{l}\text { C2-7 SP engagement } \\
\text { (lat view) }\end{array}$ & $\begin{array}{l}\text { - In sequence } \\
\text { - Moderately out of sequence } \\
\text { - Markedly out of sequence }\end{array}$ & $\begin{array}{l}\text { - In sequence } \\
\text { - Not in sequence }\end{array}$ \\
\hline C2-7 SP coupled movement (AP view) & $\begin{array}{l}\text { - In sequence } \\
\text { - Moderately out of sequence } \\
\text { - Markedly out of sequence } \\
\end{array}$ & $\begin{array}{l}\text { - In sequence } \\
\text { - Not in sequence }\end{array}$ \\
\hline C2-7 Facet gapping (AP view) & $\begin{array}{l}\text { - Insignificant } \\
\text { - Noticeable } \\
\text { - } \text { Marked } \\
\end{array}$ & $\begin{array}{l}\text { - Insignificant } \\
\text { - Not insignificant }\end{array}$ \\
\hline C2-7 Facet gapping (obl view) & $\begin{array}{l}\text { - Insignificant } \\
\text { - Noticeable } \\
\text { - Marked } \\
\end{array}$ & $\begin{array}{l}\text { - Insignificant } \\
\text { - Not insignificant }\end{array}$ \\
\hline C2-7 facet symmetry (obl view) & $\begin{array}{l}\text { - Symmetrical } \\
\text { - Mildly-Asymmetrical } \\
\text { - Asymmetrical }\end{array}$ & $\begin{array}{l}\text { - Symmetrical } \\
\text { - Asymmetrical }\end{array}$ \\
\hline
\end{tabular}

Abbreviations: $\mathrm{AP}=$ anterior to posterior, lat = lateral, obl = oblique, $\mathrm{mm}=$ millimeters, $\mathrm{R} \& \mathrm{~L}=$ right and left, c-spine $=$ cervical spine 
Table 3. Crude associations between injured and uninjured groups 


\begin{tabular}{|c|c|c|c|}
\hline & Symptomatic, $\mathrm{n}=119$ & Asymptomatic, $n=77$ & P-value* \\
\hline \multicolumn{4}{|c|}{ Demographic (\%) } \\
\hline Female, n (\%) & $90(75.6)$ & $36(46.8)$ & $<0.0001$ \\
\hline Age, mean (se) & $40.5(1.26)$ & $33.9(1.36)$ & 0.0006 \\
\hline \multicolumn{4}{|c|}{ Abnormal VF finding count (\%) } \\
\hline Total abnormal VF findings, mean (se) & $7.0(0.36)$ & $1.2(0.13)$ & $<0.0001$ \\
\hline C1-C2 lat overhang (AP), n (\%) & 75 (63.6) & $25(32.5)$ & $<0.0001$ \\
\hline C1-C2 peri-odontoid (AP), n (\%) & 34 (28.8) & $3(3.9)$ & $<0.0001$ \\
\hline \multicolumn{4}{|l|}{ C2-7 translation (lat), n (\%) } \\
\hline $\mathrm{C} 2-\mathrm{C} 3$ & 38 (31.9) & $2(2.6)$ & $<0.0001$ \\
\hline C3-C4 & $13(11.0)$ & $9(11.7)$ & 0.88 \\
\hline C4-C5 & 58 (48.7) & $19(24.7)$ & 0.001 \\
\hline C5-C6 & 23 (19.3) & $2(2.6)$ & 0.001 \\
\hline C6-C7 & $3(2.5)$ & $0(0)$ & 0.16 \\
\hline \multicolumn{4}{|l|}{ C2-7 intervertebral angulation (lat), n (\%) } \\
\hline $\mathrm{C} 2-\mathrm{C} 3$ & $5(4.2)$ & $0(0)$ & 0.07 \\
\hline C3-C4 & $8(6.7)$ & $1(1.3)$ & 0.08 \\
\hline C4-C5 & $30(25.2)$ & $6(7.8)$ & 0.002 \\
\hline C5-C6 & $10(8.4)$ & $3(3.9)$ & 0.22 \\
\hline C6-C7 & $4(3.4)$ & $0(0)$ & 0.1 \\
\hline \multicolumn{4}{|l|}{ C2-7 SP engagement (lat), $n$ (\%) } \\
\hline $\mathrm{C} 2-\mathrm{C} 3$ & $2(1.7)$ & $0(0)$ & 0.25 \\
\hline $\mathrm{C} 3-\mathrm{C} 4$ & $15(12.6)$ & $1(1.3)$ & 0.005 \\
\hline $\mathrm{C} 4-\mathrm{C} 5$ & $28(23.7)$ & $0(0)$ & $<0.0001$ \\
\hline C5-C6 & $30(25.2)$ & $0(0)$ & $<0.0001$ \\
\hline $\mathrm{C} 6-\mathrm{C} 7$ & $12(10.2)$ & $0(0)$ & 0.004 \\
\hline \multicolumn{4}{|l|}{ C2-7 SP coupled motion (AP), n (\%) } \\
\hline $\mathrm{C} 2-\mathrm{C} 3$ & $3(2.6)$ & $0(0)$ & 0.16 \\
\hline C3-C4 & $11(9.4)$ & $0(0)$ & 0.006 \\
\hline C4-C5 & $32(27.4)$ & $0(0)$ & $<0.0001$ \\
\hline C5-C6 & 49 (41.9) & $3(3.9)$ & $<0.0001$ \\
\hline $\mathrm{C} 6-\mathrm{C} 7$ & $33(28.2)$ & $2(2.6)$ & $<0.0001$ \\
\hline \multicolumn{4}{|l|}{ C2-7 facet gapping (AP), n (\%) } \\
\hline $\mathrm{C} 2-\mathrm{C} 3$ & $1(0.9)$ & $0(0)$ & 0.41 \\
\hline C3-C4 & $14(12.1)$ & $0(0)$ & 0.002 \\
\hline C4-C5 & $40(34.5)$ & $3(3.9)$ & $<0.0001$ \\
\hline C5-C6 & $44(37.9)$ & $0(0)$ & $<0.0001$ \\
\hline C6-C7 & $15(12.9)$ & $1(1.3)$ & 0.004 \\
\hline \multicolumn{4}{|l|}{ C2-7 facet gapping (obl), n (\%) } \\
\hline $\mathrm{C} 2-\mathrm{C} 3$ & $3(2.6)$ & $0(0)$ & 0.16 \\
\hline C3-C4 & $14(12.0)$ & $0(0)$ & 0.002 \\
\hline C4-C5 & $56(47.9)$ & $1(1.3)$ & $<0.0001$ \\
\hline C5-C6 & 49 (41.9) & $2(2.6)$ & $<0.0001$ \\
\hline C6-C7 & $7(6.0)$ & $1(1.3)$ & 0.11 \\
\hline \multicolumn{4}{|l|}{ C2-7 facet symmetry (obl), n (\%) } \\
\hline $\mathrm{C} 2-\mathrm{C} 3$ & $3(2.6)$ & $0(0)$ & 0.16 \\
\hline C3-C4 & $10(8.6)$ & $0(0)$ & 0.008 \\
\hline C4-C5 & $32(27.4)$ & $3(3.9)$ & $<0.0001$ \\
\hline
\end{tabular}


*t-test for Age and Total abnormal VF findings; Chi-square for all others. Abbreviations: AP = anterior to posterior view, lat $=$ lateral view, obl = oblique view, $\mathrm{mm}=$ millimeters, $\mathrm{R} \& \mathrm{~L}=$ right and left, $\mathrm{SP}=$ spinous process, c-spine $=$ cervical spine.

Table 4. Modeling Results

\begin{tabular}{l}
\hline \multirow{2}{*}{} \\
\cline { 2 - 7 }
\end{tabular}

*Model used C4-C5 facet gapping as exemplar abnormal VF parameter **Adjusted for age and sex. ROC = receiver operating characteristic

\section{Figures}

\section{Model 3 diagnostics, cut-point analysis}

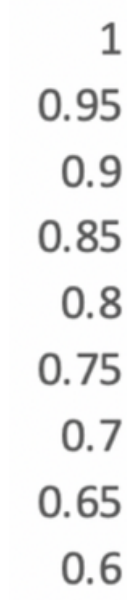

1

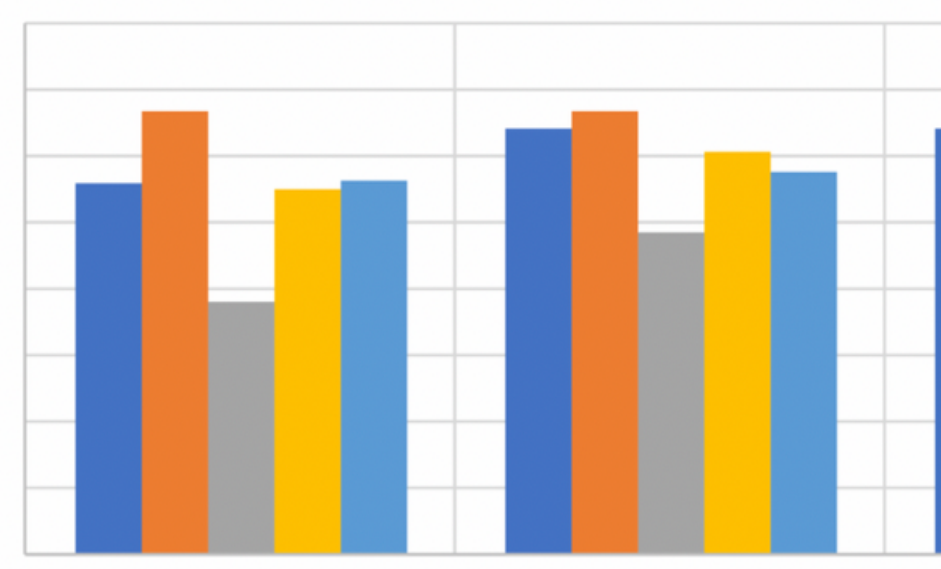

$2+$

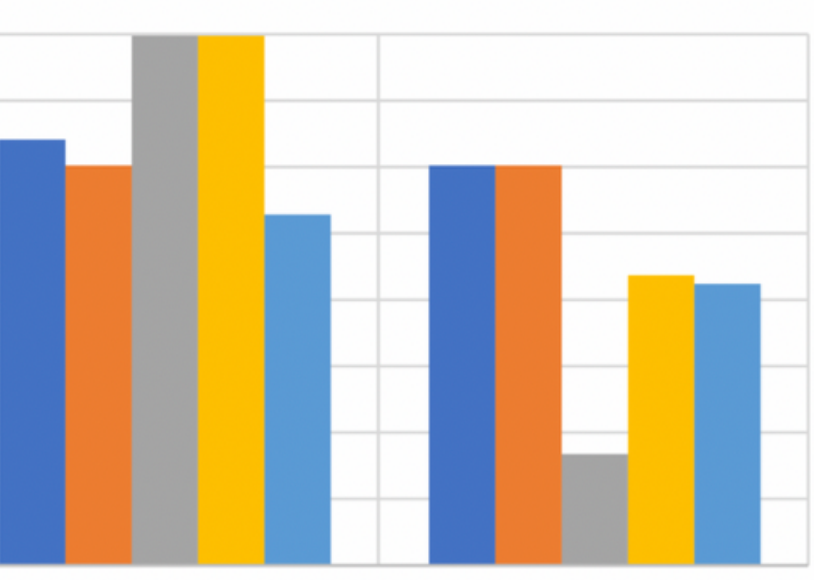

$4+$

Dichotomous model based on number of abnormal findings, adjusted for age and sex 
Figure 1

Diagnostic accuracy results for Model 3

\section{Supplementary Files}

This is a list of supplementary files associated with this preprint. Click to download.

- STARD2015ChecklistVFstudy.docx

- DMXPaperAnalysisDataSet.xlsx 